\title{
Psycholinguistic Aspects of the Internet Memes' Visual Components
}

\section{Психолингвистические аспекты визуальных компонентов интернет-мемов}

\section{Tatayna Khraban}

Ph.D. in Philology

\section{Татьяна Храбан}

кандидат филологических наук

\section{E-mail: Xraban.Tatyana@gmail.com orcid.org/0000-0001-5169-5170}

National Aviation University

1, Kosmonavta Komarova Str., Kyiv, Ukraine, 03058
Национальный авиационный университет

ул. Космонавта Комарова, 1, Киев, Украина, 03058

Original manuscript received November 06, 2018

Revised manuscript accepted August 15, 2019

\begin{abstract}
The aim of the article is to describe mechanism of the influence of the Internet memes' visual components upon consciousness; to analyze functional and semantic relationships between visual and verbal components; to research role models (character types) of the internauts who are the creators of Internet memes with wolf as a visual component; emotional states created by Internet memes.

Psycholinguistic research methods have helped to achieve this goal, namely, discourse analysis, the method of contextual and intuitive logical interpretation analysis, content analysis.

Discussion \& Results. Internet meme creators achieve communicative purpose by means of the wolf image due to the use of ramified conscious and unconscious associative links. The correspondence of the meaning originally put by the author in the Internet meme with its comprehension by the addressee occurs through the use of anchoring techniques which mechanism of impact is based on linking human states to certain patterns of behavior. "Anchors" usually work automatically therefore the
\end{abstract}


emotional state of a person changes positively or negatively without the possibility of its regulation by the addressee. With the help of visual images Internet memes create a model world of emotions. The ultimate goal of such polycode messages is mental effect on consciousness through the method of psychological infection. As soon as an addressee's emotional mood to be in a ready state to apprehend the message the meanings of the visual image which may be expressed explicitly or implicitly are developed in the verbal corpus of an Internet meme. In this study the Internet memes' verbal components were divided into thematic groups (TG) describing the internauts' emotional states. Based on the analysis of the TG it is possible to describe the role model of the Internet meme creator manifested in the features of communicative behavior. The analysis of the TG has proved that in the verbal component the internauts intend to position the background of their mental world with the corresponding emotional tone. It should be noted that verbal and visual components do not compete but complement each other, enrich the Internet meme with new meanings accumulating cultural and emotional-evaluative meanings, social stereotypes of consciousness.

Conclusion. The function of the visual component is to form a special emotional tone of the information, to provide a holistic and at the same time flexible understanding of a particular message due to placing semantic accents allowing the recipient to specify the perception and interpretation of the verbal component. The link between the visual and verbal parts of Internet memes is implicit. The information presented in the visual component is based on various associative links therefore; its interpretation requires careful correlation between both components, identification of internal structural and semantic links.

Key words: visual component, verbal component, Internet memes, emotional and mental impact.

\title{
Вступление
}

\begin{abstract}
Мультипарадигмальный и междисциплинарный характер современных лингвистических исследований открывает широкие перспективы для разработки научных теорий, имеющих несомненную теоретическую и практическую ценность за счет интеграции возможностей видения исследуемого объекта в разных ракурсах. Речь в данном случае идет о подлинной интеграции, ведущей к возникновению нового понимания сущности явления (Залевская, 2007). Появление психолингвистики дало возможность преодолеть одностороннее изучение фактов и обратить пристальное внимание на природу и сущность визуальных форм, специфику
\end{abstract}


их функционирования в коммуникации, изменение взаимосвязи и взаимодействия дополняющих друг друга визуального и вербального кодов культуры. Принимая во внимание сложность и противоречивость процесса визуализации современной коммуникации, а именно превращение визуального образа в «новую иконичность, искусственно сконструированную, мозаичную картину, вводящую индивида в мир социального опыта» (Донцов \& Дроздова, 2013: 26), исследование визуальных форм коммуникации должно быть вписано в контекст междисциплинарных исследований, в котором, «необходимо рассмотреть широкий спектр социальных и психологических параметров» (Dontsov \& Perelygina, 2011: 317). Визуальные формы коммуникации были исследованы рядом специалистов в области психолингвистики и медиалингвистики, в частности: Д. Кэмпа-Фигурой (2019) акцентировано внимание на стилистических особенностях интернет-мемов, Л. Лободенко (2016) охарактеризовано особенности трансформации медиаконтента интернет-СМИ в социальных сетях, Т. Бородулькиной (Бородулькіна, 2012) рассмотрено метафорический тренинг как инновационную психотехнологию обучения, Т. Яценко (2012) исследовано взаимосвязь между сферами сознания и бессознательного, Е. Ивашкевичом (Івашкевич, 2018) описано использование визуальных элементов для обеспечения точности восприятия переходных моментов в пространстве и времени, J. Lankow, J. Ritchie \& R. Crooks (2012) выявели механизмы воздействия на сознание визуальных образов и другими. Несмотря на достаточное количество работ, посвященных изучению, как самих визуальных феноменов, так и семиотически осложненных текстов, в структуру которых входят визуальные компоненты, исследование особенностей визуальных образов в контексте их функционирования в интернет-мемах определяет актуальность данной статьи. Цель статьи - описать механизм воздействия на сознание визуальных составляющих интернет-мемов; проанализировать функционально-семантические отношения между визуальными и вербальными компонентами; характеризировать ролевые модели (типажи) интернафтов - создателей интернетмемов с визуальным компонентом волк, а также навеиваемые ими эмоциональные состояния. 


\section{Методы и методика исследования}

Исследование проводилось в украинском секторе социальной сети Facebook. Материалом исследования послужили 214 интернетмема, визуальные компоненты которых содержат изображение волка.

Продуктивное научное описание и истолкование внутренних глубинных смыслов вербальных и визуальных компонентов интернет-мемов, выявление механизмов их воздействия на сознание стало возможным только с опорой на психолингвистические и психосемиотические теории знака, которые позволили вскрыть глубинные смыслы, транслируемые каждым из компонентов, эксплицировать ассоциации, навеянные составляющими интернетмема. Для достижения поставленной цели считаем оправданным использование таких психолингвистических методов исследования как дискурс-анализ, метод контекстуального и интуитивнологического интерпретационного анализа, контент-анализ.

По мнению L. Wood \& R. Kroger, «дискурс-анализ ...следует рассматривать как совокупность взаимосвязанных подходов, предусматривающих не только сбор и обработку информации, но и ряд теоретических предположений, а также систему принципов и методов исследования» (Wood \& Kroger, 2000: 10). Метод контекстуального и интуитивно-логического интерпретационного анализа был направлен на выявление смыслов как визуальных, так и вербальных компонентов интернет-мемов на основании своего личного опыта и логических размышлений. Контент-анализ использовался для выделения определенных смысловых единиц содержания и формы информации в тематические группы, что дало возможность выявить характерные эмоционально-психологические характеристики интернафта и его сообщения.

\section{Результаты исследования}

В современном социокультурном пространстве, каким предстает перед нами интернет, идет процесс сочетания и взаимодополняемости множества вербальных и визуальных кодов, режимов видения, техник и практик визуальности, «при этом вербальное восприятие смысла в значительной степени теряет свое 
значение, уступая место визуальному мировосприятию» (Жигарева, 2011: 11). За этапами этой трансформации позволяют наглядно проследить интернет-мемы, которые в широком понимании определяются как «мультимодальные символические артефакты, которые созданы, распространены и переданы бесчисленными опосредованными участниками культуры» (Milner, 2013: 2359), комплексные феномены интернет-коммуникации, представляющие собой целостные, завершенные единицы с текстом и картинкой в квадратной рамке. Полимодальные интернет-мемы (транслирующие информацию несколькими каналами передач) считаются каноническими, «образцовыми интернет-мемами» (Канашина, 2018). В интернет-мемах спектр вербальных и невербальных компонентов сознательно моделируется, что позволяет интернафтам решить проблему организации наиболее эффективной коммуникации. Учитывая тот негативный аспект визуализации, суть которого заключается в том, что она часто уводит от адекватного понимания послания, когда смысл замещается тем близким опыту и мышлению адресанта содержанием, которое спонтанно возникает в его сознании при поверхностном восприятии (Бородина, Еманова \& Яо, 2012), перед визуализацией, как инструментом эффективной коммуникации, ставятся такие основные задачи: содействие в восприятии и обработке огромного массива информации путем обеспечения четкости и системности в ее подаче; транслирование смыслов в концентрированной, легко узнаваемой форме, что обеспечивает быстроту коммуникативных процессов; участие в быстром и правильном ее декодировании (Antón-méndez, 2017).

Органическая включенность изображений в систему культурных кодов, ревалентность и многообразие символической наполненности свидетельствуют об информативной ценности визуальных образов, их значительном эвристическом потенциале, что «в значительной степени связано с ведущей ролью зрительного восприятия в системе чувственного освоения человеком окружающей действительности, с тем, что человек выстраивает «синтаксис бытия» посредством опыта, имеющего в своём основании визуальные формы» (Стризое \& Храпова, 2018: 194). М. Кухта (2013) отмечает, что не признаки предмета, а его насыщенность особыми смыслами - семантика - играет основную роль в создании визуального образа. 
Для более полноценного осмысления психологического аспекта феномена визуализации, по нашему мнению, следует обратиться к работам Л. Мардиевой (2015), L. Ries (2015), V. Woolf (1990). Так, Л. Мардиева утверждает, что итогом процесса транспозиции образов в сознание адресата «является формирование ментального образования, связывающего воедино прошлое и настоящее знание, бывшее и настоящее переживание и выступающего в роли интегративного органа, называемого «образом психического состояния», «эмоциональной памятью», «следами эмоциональных реакций», «визуальным воспоминанием» (Мардиева, 2015: 37). Для объяснения существования у визуальных образов повышенной силы эмоционального воздействия, L. Ries (2015) обращается к метафоре, в которой вербальный компонент - это что-то вроде гвоздя, и, чтобы вбить его в сознание адресата, нужен своего рода молоток визуальный образ. В нашем исследовании таким «визуальным молотком» выступает образ волка. Достижения автором интернетмема поставленной им коммуникативной цели происходит через образ волка благодаря эксплуатации разветвленных осознаваемых и неосознаваемых ассоциативных связей, как для создания необходимого психологического состояния адресата, так и для побуждения его к активности в нужном направлении. При помощи визуальных образов интернет-мемы создают модельный мир эмоций (Бородулькина, 2017), конечная цель таких поликодовых сообщений - осуществление психического воздействия на сознание путем метода заражения. Благодаря стремительному росту числа пользователей, интернет-коммуникация является благоприятной средой именно для такого типа психологического воздействия, о чем свидетельствует появление в социальной сети Facebook таких групп, как «Мудрость волка», «Волки и люди», «Волки и ангелы», основной контент которых представляют интернет-мемы, в которых визуальный компонент - изображение волка.

После формирования эмоционального настроя адресата, который оказывается в состоянии готовности для восприятия сообщения, эксплицитно или имплицитно выраженные смыслы визуального образа получают дальнейшее развитие в вербальном корпусе интернет-мема. Функционально-семантические отношения между визуальными и вербальными компонентами представлены в форме интерпретаций-комментариев, которые оформляются в виде 
словесных высказываний-пояснений. Создатель интернет-мема осознанно подбирает такие единицы языка, которые актуализируют в речи эмотивные смыслы с различными (положительными и отрицательными) эмоциональными зарядами с целью пробуждения интереса к сообщаемой информации. Представленный в интернетмемах визуальный образ волка представляет какой-либо фрагмент целого образа, который под влиянием вербальной составляющей актуализирует в сознании адресата эмоционально-оценочные семантические приращения.

В данном исследовании вербальные компоненты массива интернет-мемов были поделены на тематические группы (ТГ) по принципу определения эмоциональных состояний интернафтов, базируясь на анализе которых представляется возможным описать ролевую модель создателя интернет-мема, проявляющуюся в особенностях коммуникативного поведения и стиле творчества. Каждая ролевая модель (типаж) «может быть описана определенными параметрами, характеризующими мотив, декларируемую цель, опорный прием коммуникатора» (Дорожкин, 2015: 158). В соответствии с классификацией эмоциональных состояний, предложенной В. Дорожкиным (2015), нами были сформированы следующие ТГ, которые представлены в порядке убывания их удельного веса:

1. «Агрессия, активное противостояние, ненависть, гнев, конфликт, деструкция» - 31,0\% (рис. 1).

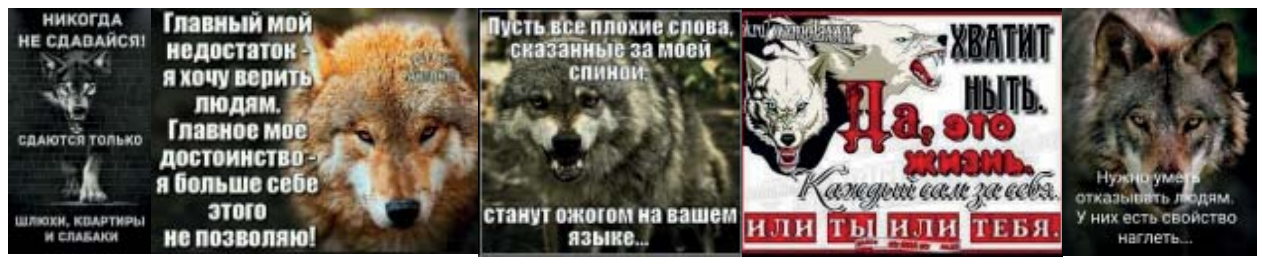

Рис. 1. Отображение в интернет-мемах агрессии, противостояния, ненависти, гнева

Интернафты, в чьих интернет-мемах присутствуют маркеры эмоционального состояния агрессии, активного противостояния, ненависти, гнева, конфликта, деструкции, склонны к выстраиванию отношений, строящихся на оппозиции «свой - чужой» (Говорят, что у меня нет СОВЕСТИ. Но я особенно не переживаю - $у$ 
некоторых нет МОЗГОВ, но они же живут как-то; Свободой надо дорожить! И не дарить себя кому попало. Голодным волком лучше быть, чем жрать все то, что перепало; У меня свой путь к счастью... и я не люблю, когда мне навязывают чужие маршруть). В рамках таких отношений они чувствуют свою защищенность, уверенность в будущем (Я не боюсь врагов и их ударов низких!; Время покажет, кто под кого ляжет). Авторы интернет-мемов этой ТГ идентифицируют себя с агрессорами (порву любого, внутренний зверь), но и от других ждут враждебности и нападения (удары в спину, испьтал друзей измену, бумеранг в твоей спине). Они стремятся к контролю и доминированию (Хватит ныть. Да. Это жизнь. Каждый сам за себя. Или ты, или тебя; Нужно уметь отказывать людям. У них есть свойство наглеть), их чувства заменены правилами и внутренними уставами (Поживу - увижу, доживу - узнаю, выюиву - учту; Уходят, чтобы вернуться только корабли. Все остальное обмену и возврату не подлежит!). Прощение как эмоциональное переживание не представлено в созданных данным типажом интернет-мемах, им знаком только опыт наказания (боль поставит всех на место, счет по полной всем оплачивать придется). В то же время они эмпатийны в отношении к чужому страданию, так как чувствуют в них отголоски собственных переживаний (Я желаю каждому не иметь в друзьях тварь продажную; Не уньвай, не огорчайся, наплюй на зависть и на лесть, ни перед кем не прогибайся, и будь таким, какой mbl ecmb).

2. «Апатия, фрустрация, страдание, депрессия» - 28,0\% (рис. 2).
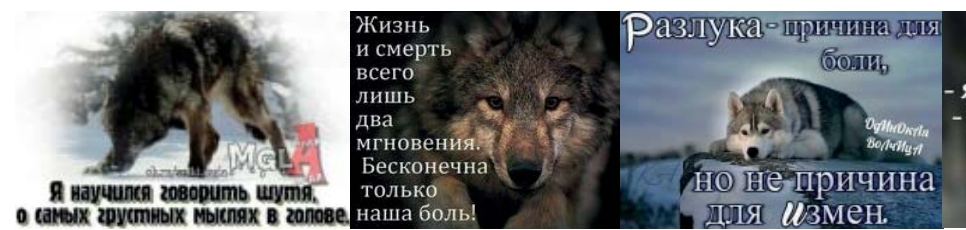

- У тебя есть шрамы?

Я полностью ими покрыт.

Но я не вижу ни одного?

- А ты просто.

саных zрустных нылnях в zоnoвe. наша боль!

загляни мне в душу.

Рис. 2. Отображение в интернет-мемах апатии, фрустрации, страдания, депрессии

Интернафтам, позиционирующим эмоциональное состояние апатии, фрустрации, страдания, депрессии, присущи негативные переживания любых событий (жизнь непонятна и несправедлива; 
Psycholinguistic Aspects of the Internet Memes' Visual...

как же сложно жить, когда воспринимаешь все близко к сердиу), им свойственны пессимистические ожидания от жизни в целом (любимого человека нельзя заменить никем и никогда; трудно понять, как жить дальше будешь), у них сниженный фон настроения (как трудно, уже не в силах, как больно, как жаль, это ужасно, разорванная душа, душа в сплошных ушибах, мучиться, paны на сердцее), они ощущают себя чужим, лишним в коллективе (Я здесь чужсой! Я из другого мира! Оиибся Бог, сюда меня послав; одиночка). Других они идентифицируют с равнодушными в отношении них субъектами (я умирал в душе, а люди проходили мимо; людям плевать на твои чувства), испытывают пренебрежение или даже отвержение (странные люди пошли: сами врут, а от других требуют правды). Такие люди склонны к самодеструкции (умирал в душе), они страдают в результате утраты объекта любви, но, пассивно пребывая в этом состоянии, не стараются его изменить (в душу в основном западают те люди, для которых мы ничего не значим) или просто не верят в любовь (жить среди невылолненных обещзаний и поддельной любви).

3. «Нарциссическое подобие и рекурсия (осознание мотивов, причин и символики своих поступков)» - 24,0\% (рис. 3).

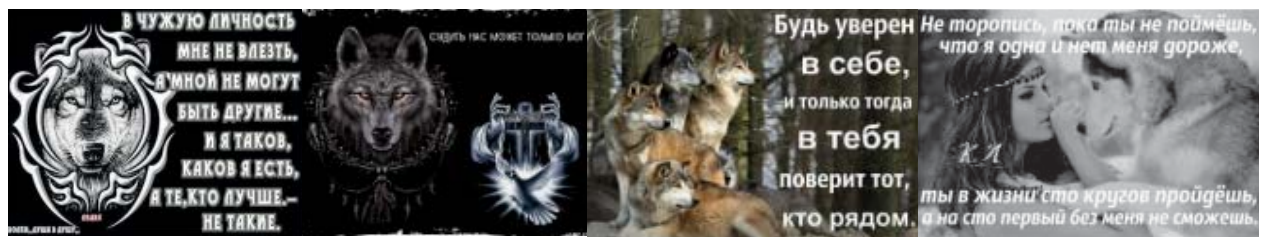

Рис. 3. Нарииссическое подобие и рекурсия в интернет-мемах

Интернафты ролевой модели нарциссизма замкнуты сами на себе, а в сферу их эмоций не включены чужие переживания и чувства (Я никогда не проигрываю: либо я побеждаю, либо игра ещуе не закончена; Я их тех, кто любит молча, терпит долго, уходит резко; Если я люблю, то больше жизни. Если дружу, то навсегда. Если предан, то до конца). Переживания, опыт отношений и чувства такой ролевой модели являются мерилом всему (Я никому ничего не доказываю. Не переубеждаю. Не навязываю. У меня своя правда. Свое мнение. Так было, есть и будет), у них не сформирована установка на понимание и признание Другого (Я не изменюсь, меня 
воспитали не под вкусы окружающуих; Не учите меня жить. Ведь я вас тому не учу. Не удастся меня изменить - буду жить, как сам того хочу!). Рассматривая собственные переживания через призму самого себя, такой типаж ищет некую символическую точку опоры, но не во внешнем пространстве, а в самом себе (Не бойся кого-то потерять, бойся потерять себя!).

4. «Любовь, принятие и внутреннее счастье» - 17,0\% (рис. 4).

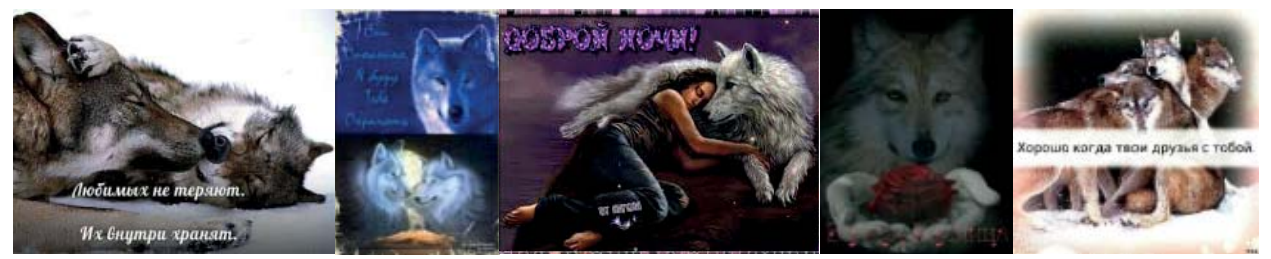

Рис. 4. Отображение в интернет-мемах любви, принятия и внутреннего счастья

Анализ этой ТГ свидетельствует, что интернафтам, позиционирующим позитивные эмоции, свойственна амбивалентность в отношении к собственному «Я»: с одной стороны, они воспринимают себя как значимую фигуру в отношениях (Если вы увидели боль в глазах близкого человека, не закрывайте на это глаза! Возможно, именно вы способны ее oтmуда убрать), но с другой стороны - партнер обладает для них приоритетностью (Я о тебе подумав, ульбнусь. Вздохну, что далеко ты от меня. И Богу еле сльшино помолюсь, желая, чтоб хранил тебя). Они интенционально стремятся к установлению позитивных отношений (Стая мудрых, родная стая! Пусть ваш вечер будет радостью для вас!!!; Мне нравятся простье люди, которые легки в общении, которые не стараются красоваться перед кем-то, которые искренне к тебе относятся, без всяких корыстных цуелей. Люди, чьи ульбки поднимают мое настроение; Спасибо тем, которые стали родныли не по крови, а по жизни), старается индуцировать чувства любви, принятия и внутреннего счастья у референтного ему окружения (Цените тех, кто рядом в трудную минуту. Любите тех, кто не предаст. Цените тех, кто Вам протянет руку и никогда, и никому Вас не отдаст; Если у вас есть такая возможность, помогайте людям, иногда доброе слово значит намного больие, чем все сокровища мира; Любите тех, 
кто просто рядом, кто не посмеет изменить, кто вас ласкает тепльлм взглядом, кто просто помогает жить). Это происходит даже тогда, когда переживания принятия и любви наталкиваются на трудности (Когда по-настоящему любишь, то любишь все в человеке: его злость, его грусть, его радость - все, что есть в нем). Другой особенностью интернафтов данной ролевой модели является то, что они остро переживают чувство несправедливости, им трудно жить в конфликте, они стремятся к уходу из ситуации эмоциональной холодности (Оиибается каждый. Признает ошибки мудрый. Просит прощуения сильный. Восстанавливает отношения любящуии; Я не хочу, чтобы меня лечило время, я просто не хочу никем болеть).

Таким образом, каждый типаж стремится позиционировать в вербальном компоненте фон своего психического мира, который обладает соответствующим эмоциональным окрасом. При этом, вербальные и визуальные составляющие не конкурируют, a дополняют друг друга, обогащают интернет-мем новыми смыслами, аккумулируя культурные и эмоционально-оценочные смыслы, социальные стереотипы сознания, которые превращают его в «овеществленный репрезентант культурного знака данного коммуникативного сообщества» (Мардиева, 2012: 77), и позиционируют чувства интернафтов - «сложную форму представления мира в сознании человека, обобщающие эмоции и понятия и непосредственно связанной с нуждами и мотивами деятельности человека» (Мардиева, 2015: 5).

\section{Выводы}

Визуальный образ в интернет-меме формирует особую эмоциональную тональность посыла, обеспечивает целостное и в то же время гибкое понимание конкретного сообщения путем расстановки смысловых акцентов, позволяющих адресату конкретизировать восприятие и интерпретацию вербальной составляющей. Единство системы знаков (вербальных и визуальных) решает общую задачу: стремление вызвать у адресанта особое эмоциональное состояние, что является наиболее действенным способом оказания суггестивного воздействия. Связь 
между визуальной и вербальной частями интернет-мемов носит имплицитный характер. Информация, представленная в визуальном компоненте, основывается на различных ассоциативных связях, поэтому ее интерпретация требует тщательного соотнесения обоих компонентов, выявления внутренних структурносемантических связей.

Перспективой дальнейших исследований является дальнейшая разработка данной темы в контексте анализа интернет-мемов с позиции суггестивной лингвистики.

\section{Литература}

Бородина, С.Д., Еманова, Ю.Г., \& Яо, М.К. (2012). Методологические аспекты интерпретации художественной культуры. Стратегии визуализации $u$ вербализации социокультурных практик (с. 184-198). Казань.

Бородулькіна, Т.О. (2012). Метафоричний тренінг як інноваційна психотехнологія навчання студентів-психологів. Гуманітарний вісник, 27(39), 81-90.

Бородулькина, Т.А. (2017). Метафора руки как проективный материал в работе практического психолога. East European Journal of Psycholinguistics, 4(1), 17-29. https://doi.org/10.5281/zenodo.824023

Дорожкин, B.P. (2015). Эмоциональные дискурсы в психотерапии. Консультативная психология и психотерапия, 2, 155-171. https:/doi. org/10.17759/cpp.2015230210

Донцов, А.И., \& Дроздова, А.В. (2013). Визуальное воздействие интернетрекламы на молодежную субкультуру. Национальный психологический журнал, 2(10), 25-31. https://doi.org/10.11621/npj.2013.0203

Жигарева, А.А. (2011). Визуализация сочичального пространства современного общества: сочиильно-философский анализ. (Дисс. канд. философ. наук). Москва: Воен. ун-т.

Залевская, А.А. (2007). Динамика общенаучных подходов к проблеме знания и некоторые задачи психолингвистических исследований. Bonpocbl психолингвистики, 5, 4-12.

Івашкевич, Е. (2018). Психолінгвістичні аспекти наративу: сприйняття звуку та кольору. Педагогіка і психологія професійної освіти, 1, 137-144.

Канашина, С.В. (2018). Интернет-мем как современный медиадискурс. Известия Волгоградского государственного педагогического университета, 8(131), 125-129.

Кэмпа-Фигура, Д. (2019). (Интернет-)мем как новый медиа жанр. Постановка вопроса. Медиалингвистика, 6(1), 103-121.

Кухта, М.С. (2013). Инвариантность семантики в модели создания визуального образа дизайна. Известия Томского политехнического университета, 6(323), $223-226$.

Лободенко, Л.К. (2016). Региональные интернет-СМИ в социальных сетях: трансформация медиаконтента. Филологические науки. Bопросы теории и практики, 5, 29-34. 
Мардиева, Л.А. (2015). Виртуальная действительность в языковой и внеязыковой репрезентации (на материале медиатекстов). (Автореф. дисс. д-ра филол. наук). Казань: Приволж. федер. ун-т.

Мардиева, Л.А. (2012). Психосоциальная модель знака. Филология и культура, 2(28), 76-79.

Стризое, А.Л., \& Храпова, В.А. (2018). Вербальное и визуальное в культуре: иерархия или дополнительность? Bопросы философии, 6, 194. https://doi. org/10.7868/S004287441806016X

Яценко, Т.С. (2012). Визуализация психического в целях его глубинного познания. Психолінгвістика, 11, 142-160.

Antón-méndez, I. (2017). Visual salience effects on speaker choices: Direct or indirect influences on linguistic processing? Applied Psycholinguistics, 38(3), 601-631. https://doi.org/10.1017/S0142716416000345

Dontsov, A.I., \& Perelygina, E.B. (2011). Security Problems of Communicative Strategies. Psychology in Russia: State of the Art, 4, 316-323. https://doi. org/10.11621/pir.2011.0020

Lankow, J., Ritchie, J., \& Crooks, R. (2012). Infographics: the Power of Visual Storytelling. New Jersey: John Wiley \& Sons Inc.

Milner, R. (2013). Pop polyvocality: Internet memes, public participation, and the Occupy Wall Street movement. International Journal of Communication, 7, 2357-2390.

Ries, L. (2015). Visual hammer: Nail Your Brand into the Mind with the Emotional Power of a Visual Hammer. Publisher: Ries \& Ries.

Woolf, V.V. (1990). Holodynamics: How to Develop and Manage Your Personal Power. Publisher: Harbinger House.

Wood, L.A., \& Kroger, R.O. (2000). Doing discouse analisis: Methods for studying action in text and talk. Thousand Oaks, CA: Sage.

\section{References}

Borodina, S.D., Emanova, Yu.G., \& Yao, M.K. (2012). Metodologicheskie aspektyi interpretatsii hudozhestvennoy kulturyi [Methodological aspects of the artistic culture interpretation]. Strategii vizualizaczii $i$ verbalizaczii socziokulturnykh praktik - Strategies for visualizing and verbalizing sociocultural practices (pp. 184-198). Kazan [in Russian].

Borodulkina, T.O. (2012). Metaforichniy trening yak Innovatsiyna psihotehnologiya navchannya studentiv-psihologiv [Metaphorical training as an innovative psychotechnology for students-psychologists]. Gumanitarniy visnik Humanitarian Herald, 27(39), 81-90 [in Ukrainian].

Borodulkina, T. (2017). Metafora ruki kak proektivny` $\mathrm{j}$ material $\mathrm{v}$ rabote prakticheskogo psikhologa [The Hand Metaphor as a Projective Tool of Applied Psychologist]. East European Journal of Psycholinguistics, 4(1), 17-29. https:// doi.org/10.5281/zenodo.824023 [in Russian].

Dorozhkin, V.R. (2015). Emotsionalnyie diskursyi v psihoterapii [Emotional discourses in psychotherapy]. Konsultativnaya psihologiya $i$ psihoterapiya Consultative psychology and psychotherapy, 2, 155-171. https://doi.org/10.17759/ cpp.2015230210 [in Russian]. 
Dontsov, A.I., \& Drozdova, A.V. (2013). Vizualnoe vozdeystvie internet-reklamyi na molodezhnuyu subkulturu [The visual impact of online advertising on youth subculture]. Natsionalnyiy psihologicheskiy zhurnal - National psychological journal, 2(10), 25-31. https://doi.org/10.11621/npj.2013.0203 [in Russian].

Zhigareva, A.A. (2011). Vizualizatsiya sotsialnogo prostranstva sovremennogo obschestva [Visualization of the social space of modern society: a sociophilosophical analysis]. Candidate's thesis. Moscow: Voennyiy universitet [in Russian].

Zalevskaya, A.A. (2007). Dinamika obshchenauchnyh podhodov k probleme znaniya i nekotorye zadachi psiholingvisticheskih issledovanij [The dynamics of general scientific approaches to the problem of knowledge and some tasks of psycholinguistic research]. Voprosy psiholingvistiki - Psycholinguistics Issues, 5, 4-12 [in Russian].

Ivashkevich, E. (2018). Psiholingvistichni aspekti narativu: spriynyattya zvuku ta koloru [Psycho-linguistic aspects of the narrative: perception of sound and color]. Pedagogika $i$ psihologiya profesiynoyi osviti - Pedagogy and psychology of professional education, 1, 137-144 [in Ukrainian].

Kanashina, S.V. (2018). Internet-mem kak sovremennyiy mediadiskurs [Internet meme as a modern media discourse]. Izvestiya Volgogradskogo gosudarstvennogo pedagogicheskogo universiteta - News of the Volgograd State Pedagogical University, 8(131), 125-129 [in Russian].

Kempa-Figura, D. (2019). (Internet-)mem kak novyiy mediazhanr. Postanovka voprosa [(Internet) meme as a new media genre. Statement of a question]. Medialingvistika - Media Linguistics, 6(1), 103-121 [in Russian].

Kuhta, M.S. (2013). Invariantnost semantiki v modeli sozdaniya vizualnogo obraza dizayna [The invariance of semantics in the model for creating a visual design image]. Izvestiya Tomskogo politehnicheskogo universiteta - News of Tomsk Polytechnic University, 6(323), 223-226 [in Russian].

Lobodenko, L.K. (2016). Regionalnye internet-SMI V soczial'ny'kh setyakh: transformacziya mediakontenta [Regional online media in social networks: the transformation of media content]. Filologicheskie nauki. Voprosy teorii $i$ praktiki - Philology. Theory and practice, 5, 29-34 [in Russian].

Mardieva, L.A. (2015). Virtualnaya deystvitelnost v yazyikovoy i vneyazyikovoy reprezentatsii (na materiale mediatekstov) [Virtual reality in the language and non-linguistic representation (on the material of media texts)]. Extended abstract of Doctor's thesis. Kazan: Privolzhskiy federalnyiy universitet [in Russian].

Mardieva, L.A. (2012). Psihosotsialnaya model znaka [Psychosocial model of the sign]. Filologiya i kultura - Philology and Culture, 2(28), 76-79 [in Russian].

Strizoe, A.L., \& Hrapova, V.A. (2018). Verbalnoe i vizualnoe v kulture: ierarhiya ili dopolnitelnost? [Verbal and visual culture: hierarchy or complementarity?]. Voprosyi filosofii - Philosophy issues, 6, 194. https://doi.org/10.7868/ S004287441806016X [in Russian].

Yatsenko, T.S. (2012). Vizualizatsiya psihicheskogo $\mathrm{v}$ tselyah ego glubinnogo poznaniya [Visualization of the mental for its in-depth knowledge]. Psiholingvistika Psycholinguistics, 11, 142-160 [in Russian].

Antón-méndez, I. (2017). Visual salience effects on speaker choices: Direct or indirect influences on linguistic processing? Applied Psycholinguistics, 38(3), 601-631. https://doi.org/10.1017/S0142716416000345 
Dontsov, A.I., \& Perelygina, E.B. (2011). Security Problems of Communicative Strategies. Psychology in Russia: State of the Art, 4, 316-323. https://doi. org/10.11621/pir.2011.0020

Lankow, J., Ritchie, J., \& Crooks, R. (2012). Infographics: the Power of Visual Storytelling. New Jersey: John Wiley \& Sons Inc.

Milner, R. (2013). Pop polyvocality: Internet memes, public participation, and the Occupy Wall Street movement. International Journal of Communication, 7, 2357-2390.

Ries, L. (2015). Visual hammer: Nail Your Brand into the Mind with the Emotional Power of a Visual Hammer. Publisher: Ries \& Ries.

Woolf, V.V. (1990). Holodynamics: How to Develop and Manage Your Personal Power. Publisher: Harbinger House.

Wood, L.A., \& Kroger, R.O. (2000). Doing discouse analisis: Methods for studying action in text and talk. Thousand Oaks, CA: Sage.

\begin{abstract}
АННОТАЦИЯ
Цель исследования заключается в описании механизма воздействия на сознание визуальных составляющих интернет-мемов; анализе функциональносемантических отношений между визуальными и вербальными компонентами; изучении ролевых моделей (типажей) интернафтов - создателей интернетмемов, визуальный компонент которых - волк, а также навеиваемых им эмоциональных состояний.
\end{abstract}

Для достижения поставленной цели были использованы психолингвистические методы исследования: дискурс-анализ, метод контекстуального и интуитивно-логического интерпретационного анализа, контент-анализ.

Результаты. Достижения автором интернет-мема поставленной им коммуникативной цели происходит через образ волка благодаря эксплуатации разветвленных осознаваемых и неосознаваемых ассоциативных связей. Соответствие смысла, который был изначально заложен автором в интернетмеме, пониманию его адресатом, происходит благодаря использованию техники якорения, механизм действия которой основан на привязке состояний человека до некоторых шаблонов поведения. Обычно "якоря» срабатывают автоматически, поэтому эмоциональное состояние человека меняется положительно или отрицательно без возможности его регулирования со стороны адресата. При помощи визуальных образов интернет-мемы создают модельный мир эмоций, конечная цель таких поликодовых сообщений - осуществление психического воздействия на сознание путем метода заражения. После формирования эмоционального настроя адресата, который оказывается в состоянии готовности для восприятия сообщения, эксплицитно или имплицитно выраженные смыслы визуального образа получают дальнейшее развитие в вербальном корпусе интернет-мема. В данном исследовании вербальные компоненты массива интернет-мемов были поделены на тематические группы (ТГ) по принципу определения эмоциональных состояний интернафтов. Базируясь на анализе ТГ, представляется возможным описать 
ролевую модель создателя интернет-мема, проявляющуюся в особенностях коммуникативного поведения. Анализ ТГ доказал, что интернафты стремятся позиционировать в вербальном компоненте фон своего психического мира, который обладает соответствующим эмоциональным окрасом. В вербальные и визуальные составляющие не конкурируют, а дополняют друг друга, обогащают интернет-мем новыми смыслами, аккумулируя культурные и эмоционально-оценочные смыслы, социальные стереотипы сознания.

Выводы. Функция визуального компонента состоит в том, что он формирует особую эмоциональную тональность посыла, обеспечивает целостное и в то же время гибкое понимание конкретного сообщения путем расстановки смысловых акцентов, позволяющих адресату конкретизировать восприятие и интерпретацию вербальной составляющей. Связь между визуальной и вербальной частями интернет-мемов носит имплицитный характер. Информация, представленная в визуальном компоненте, основывается на различных ассоциативных связях, поэтому ее интерпретация требует тщательного соотнесения обоих компонентов, выявления внутренних структурно-семантических связей.

Ключевые слова: визуальный компонент, вербальный компонент, интернетмемы, эмоционально-психическое воздействие.

\section{Храбан Тетяна. Психолінгвістичні аспекти візуальних компонентів} інтернет-мемів

\section{АНОТАЦІЯ}

Mета дослідження полягає в описі механізму впливу на свідомість візуальних складових інтернет-мемів; аналізі функціонально-семантичних відносин між візуальними і вербальними компонентами; вивченні рольових моделей (типажів) інтернафтів - творців інтернет-мемів, візуальний компонент яких - вовк, а емоційних станів, які навіює образ вовка.

Для досягнення поставленої мети були використані психолінгвістичні методи дослідження: дискурс-аналіз, метод контекстуального і інтуїтивно-логічного інтерпретаційного аналізу, контент-аналіз.

Результати. Досягнення автором інтернет-мема поставленої їм комунікативної мети відбувається через образ вовка завдяки експлуатації розгалужених усвідомлюваних $i$ неусвідомлюваних асоціативних зв'язків. Відповідність змісту, закладеному автором у інтернет-меме, розумінню його адресатом, відбувається завдяки використанню техніки якоріння, механізм дії якої базується на прив'язці станів людини до деяких шаблонів поведінки. Зазвичай "якоря» спрацьовують автоматично, тому емоційний стан людини змінюється позитивно або негативно без можливості його регулювання з боку адресата. За допомогою візуальних образів інтернет-меми створюють модельний світ емоцій, кінцева мета таких полікодових повідомлень здійснення психологічного впливу на свідомість шляхом методу зараження. 
Після формування емоційного настрою адресата, який виявляється в стані готовності для сприйняття повідомлення, експліцитно або імпліцитно виражені смисли візуального образу отримують подальший розвиток в вербальному корпусі інтернет-мема. В даному дослідженні вербальні компоненти масиву інтернет-мемів були поділені на тематичні групи (TГ) за принципом визначення емоційних станів інтернафтів. Базуючись на аналізі ТГ, представляється можливим описати рольову модель твория інтернетмема, яка виявляється в особливостях комунікативної поведінки. Аналіз ТГ довів, що інтернафти прагнуть позиціонувати в вербальному компоненті фон свого психічного світу, який має відповідне емоційне забарвлення. При цьому, вербальні і візуальні складові не конкурують, а доповнюють один одного, збагачують інтернет-меми новими смислами, акумулюючи культурні та емоційно-оціночні смисли, соціальні стереотипи свідомості.

Висновки. Функція візуального компонента полягає в тому, що він формує особливу емоційну тональність повідомлення, забезпечує цілісне і в той же час гнучке розуміння конкретного сенсу шляхом розстановки смислових акцентів, що дозволяють адресату конкретизувати сприйняття та інтерпретацію вербальної складової. Зв'язок між візуальної і вербальної частинами інтернетмемів носить імпліцитний характер. Інформація, яка представлена в візуальному компоненті, ґрунтується на різних асоціативних зв язках, тому ії інтерпретація вимагає ретельного співвіднесення обох компонентів, виявлення внутрішніх структурно-семантичних зв язків.

Ключові слова: візуальний компонент, вербальний компонент, інтернет-меми, емочійно-психічний вплив. 